\title{
Surgical management of dystocia due to dicephalic sternophagus tetrabrachius tetrapus dicaudatus monster in a Murrah buffalo
}

\author{
Ravi Dutt ${ }^{\star *}$, Usha Yadav², Sujata Jinagal ${ }^{2}$ and Sukhbir Ravish ${ }^{2}$ \\ Department of Veterinary Gynaecology\& Obstetrics \\ College of Veterinary Sciences, \\ Lala Lajpat Rai University of Veterinary and Animal Sciences, Hisar, Haryana - 125004
}

\begin{abstract}
Citation: Dutt, R., Yadav, U., Jinagal, S. and Ravish, S. 2021. Surgical management of dystocia due to dicephalic sternophagus tetrabrachius tetrapus dicaudatus monster in a Murrah buffalo. J. Vet. Anim. Sci. 52(3): 316-318. DOI: https://doi.org/10.51966/jvas.2021.52.3.316-318
\end{abstract}

Received:22.06.2021

Accepted: 12.07.2021

Published: 30.09.2021

\begin{abstract}
Successful delivery of a conjoint monster, dicephalic sternophagus tetrabrachius tetrapus dicaudatus monster by caesarean section and partial fetotomy in a Murrah buffalo is reported.
\end{abstract}

Keywords: Dystocia, conjoint monster, sternophagus, bicephalic, tetrabrachius, tetrapus, dicaudatus, caesarean section.

In bovines, the incidence of dystocia is quite high than other domestic animal species (Dutt et al., 2021). Monsters are mostly observed in cattle with an overall incidence of one in 100,000 bovine births. They are rare in other species (Roberts, 1971) but reports in buffaloes are meagre. The incidence of monstrosities encountered for cow is 0.5 per cent (Craig, 1930) whereas an incidence of 7.9 per cent to 12.8 per cent has been reported for riverine buffalo (Singla and Sharma 1992). The conjoined twins are two fetuses joined together and arise typically from a single ovum and are monozygotic that occur due to incomplete division of a fertilized ovum (Roberts, 2004). Such conjoint fetuses at the time of parturition warrants the need of obstetrical intervention and fetomaternal disproportion is consistently the most frequent overall indication for caesarean section. The present report describes a case of dystocia due to dicephalic sternophagus tetrabrachius tetrapus dicaudatus monster in a Murrah buffalo and its delivery through caesarean section.

A seven-year-old pluriparous buffalo in sternal recumbency with a history of ruptured water bag 10 hours ago along with hanging snare from vulvar lips was brought to veterinary clinical complex of the Lala Lajpat Rai University of Veterinary and Animal Sciences, Hisar. According to owner, excessive traction was applied by the field paraveterinarian staff to the presented forelimbs of the fetus with snare for about 5-6 $\mathrm{h}$ but attempts made by local paraveterinarian staff went futile.

\author{
1. Assistant Professor \\ 2. MVSc Scholar \\ ${ }^{*}$ Corresponding author: raviduttvets@yahoo.co.in
}

Copyright: (C) 2021 Dutt et al. This is an open access article distributed under the terms of the Creative Commons Attribution 4.0 International License (http://creativecommons.org/licenses/by/4.0/), which permits unrestricted use, distribution, and reproduction in any medium, provided the original author and source are credited.

316 Surgical management of dystocia due to dicephalic sternophagus tetrabrachius.. 
On clinical examination, it was found that the temperature of dam was $101^{\circ} \mathrm{F}$, heart rate was 54 beats per minute and respiration rate was 23 per minute.A thorough per-vaginal examination after epidural anaesthesia with $5 \mathrm{ml}$ of 2 per cent lignocaine and proper lubrication with liquid paraffin revealed the presence of two foetuses joined at the sternal region in anterior longitudinal presentation and dorso-iliac position with fourforelimbs and two foetal heads in the birth canal. The case was diagnosed as dystocia due to conjoint foetal monstrosity.As the case was previously handled at field level for 5-6 h, the birth canal was dried up.The animal was in sternal recumbency,the fetus was diagnosed as monster and per-vaginal delivery seemed to be impossible.Considering the physical condition of dam,an emergency caesarean section was conducted.

The animal was restrained in right lateral recumbency and incision was done at paramedian site just parallel to milk vein (four fingers lateral to milk vein) under local infiltration with 2 per cent lignocaine $\mathrm{HCl}$ and after preparing the site aseptically. Due to excessively large size and abnormal shape of fetuses, both fetuses were retrieved by careful staged foetotomy (Fig.1) and foetal membranes were removed manually. The uterus was sutured using vicryl no. 3 in two layers by Cushing and lambert suturing patterns, respectively. The first and second muscle layers were sutured by using vicryl no. 3 in lock stitch suture pattern. Skin was sutured with silk using cross mattress suture pattern.

Eight Cleanex ${ }^{\circledR}$ boli (Nitrofurazone, Metronidazole, Urea and Povidone iodine; Boehringer Ingelheim) were placed intrauterine.The animal was treated with Inj. Oxytocin 50 I.U. in 1 liter of normal saline solution IV; Inj. Calcium-magnesium-borogluconate $450 \mathrm{ml} \mathrm{I/V}$, Inj. Ceftriaxone $4 \mathrm{~g}$ I/M, Inj. Chlorpheniramine maleate $227.5 \mathrm{mg}$ $\mathrm{I} / \mathrm{M}$, Inj. Flunixinmeglumine1000mg I/M, Inj. Metronidazole $5000 \mathrm{mg} / 1000 \mathrm{ml}$ and Inj. Vit. B complex $10 \mathrm{ml} / \mathrm{M}$. Antibiotic, Vitamin-B complex and anti-inflammatory drug were advised for seven days whereas Inj. Metronidazole was recommended for three days. Antiseptic dressing with povidone iodine was advised for 12 days and skin sutures were removed on day 12 post surgery.The animal had uneventful recovery.

Grossly the monster possessed two normal heads, with separate nostrils, eyes and ears, eight limbs and two tails and the fetuses were conjoint over sternum.The sex of two fetuses was same (male). Postmortem examination of monster revealed complete development of visceral organs and musculoskeletal system in both the conjoint fetuses.

Monstrosity is due to congenital embryonic duplication of germinal layer arising from single ovum (Kumar and Reddy, 2008) that bring about monozygotic fetus with partial or complete duplication of body structures. Conjoint twins develop after the development of embryonic plate (Whitlock et al., 2008). The embryonic disk starts to differentiate on the $13^{\text {th }}$ day of conception and if the split occurs after day 13 , the twins share body parts besides sharing their chorion and amnion (Finberg, 1994). Normal per-vaginal delivery of such types of conjoint twins is difficult due to abnormal fetomaternal disproportion resulting in dystocia. Conjoint twins are always identical twins and of the same sex (Arthur et al., 2001). Such twins are usually due to non-inherited defects and often lead to severe dystocia (Roberts, 2004). Dystocia due to conjoint twin monster have been reported as rare cases in buffaloes (Selvaraju et al., 2002; Singh et al., 2013a). Foetotomy remains a good alternative to hysterectomy or caesarean section for relieving a foetal monster resulting in dystocia (Vermunt, 2009). The buffaloes subjected to caesarean section have evidenced a lower survival rate $(45.1 \%)$ in

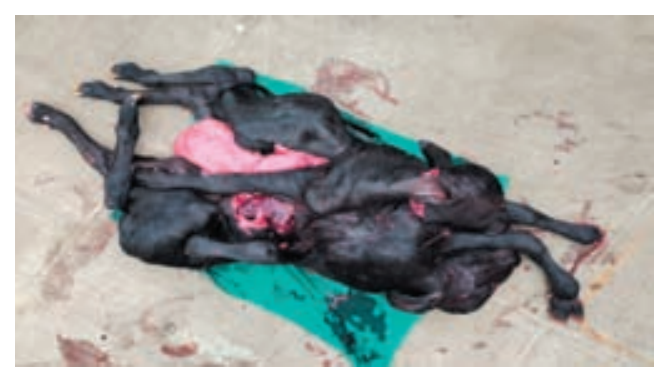

Fig. 1 Conjoint dicephalic tetrabrachius sternophagus tetrapus dicaudatus monster 
contrast to those with/without partial foetotomy (Singh et al., 2013b). So it's imperative to diagnose the foetal monstrosity at initial stages of parturition and in manipulated and delayed cases of monstrosity, the caesarean section becomes the last resort.

\section{Summary}

The present report describes a case of dystocia due to dicephalus sternophagus tetrabrachius tetrapus dicaudatus monster in a Murrah buffalo and its delivery through caesarean section.The paper discusses the causes of foetal monstrosity. The need to diagnose the condition at initial stages of parturition as caesarean section becomes the last resort in manipulated and delayed cases of monstrosity is also emphasisied.

\section{Conflict of interest}

The authors declare that they have no conflict of interest.

\section{References}

Arthur, G.H., Noakes, D.E., Parkinson, T.J. and England, G.C.W. 2001. Veterinary Reproduction and Obstetrics, $\left(8^{\text {th }} \mathrm{ed}\right)$. WB Saunders Company London.

Craig, J.F. 1930. Fleming's Veterinary Obstetrics. (4 $4^{\text {th }}$ Ed.)Bailliere. London: Tindall and Cox.

Dutt, R., V, Arjun., Kumar, G., Yadav, V. and Dalal, J. 2021. Dystocia due to fetal monstrosity in a riverine buffalo.Buffalo Bulletin.40(1): 185-187.

318 Surgical management of dystocia due to dicephalic sternophagus tetrabrachius.
Kumar, V.N. and Reddy, A.R.M. 2008. Syncephalus dipus tetrabrachius tetrapusdibrachius monster in ewe. Indian Vet.J. 85:1335.

Roberts, S.J. 1971.Veterinary Obstetrics and Genital Disease (Theriogenology).CBS Publisher and Distributor, India p. 73.

Roberts, S.J. 2004. Veterinary Obstetrics and Genital Diseases.CBS Publishers, New Delhi. India. pp. 72-73.

Selvaraju, M., Kathiresan, D. and C. Veerapandian. 2002. Dystocia due to conjoint twin monster in a buffalo a case report. Indian Vet. J.79: 721-722.

Singh, G., Pandet, A. K., Dutt, R., Sunder, S., Kumar, S. and Chander, S. 2013a. Delivery of a dicephalus sternopagus tetrabrachius tetrapus dicaudatus monster in a Murrah buffalo by caesarean section.Buffalo Bulletin.32:242-244.

Singh, G., Pandey, A.K., Agnihotri, D., Chander, S., Chandolia, R.K. and Dutt, R. 2013b. Survival and fertility rate in buffaloes following caesarean section and mutation with/without partial fetotomy. Indian J. Anim. Sci.83: 251-253.

Singla, V.K. and Sharma, R.D. 1992. Analysis of 188 cases of dystocia in buffaloes. Indian Vet. J.69: 563-564.

Vermunt, J. 2009. Fetotomy. In: Noakes, D.E., T.J.Parkinson and G,C.W. England (eds.) Veterinary Reproduction and Obstetrics. Saunders Elsevier, Oxford, Saunders Co. Ltd, London, United Kingdom, pp. $326-343$.

Whitlock, B.K., Kaiser, L. and Maxwell, H.S. 2008. Heritable bovine fetal anomalies. Theriogenology.70: 535-549. 